\title{
Educating Informal Educators on Issues of Race and Inequality: Raising Critical Consciousness, Identifying Challenges, and Implementing Change in a Youth and Community Work Programme
}

\author{
Jess Achilleos *, Hayley Douglas * and Yasmin Washbrook * \\ Faculty of Social and Life Sciences, Wrexham Glyndwr University, Wrexham LL11 2AW, UK \\ * Correspondence: j.achilleos@glyndwr.ac.uk (J.A.); h.douglas@glyndwr.ac.uk (H.D.); \\ yasmin.washbrook@glyndwr.ac.uk (Y.W.)
}

Citation: Achilleos, J.; Douglas, H.; Washbrook, Y. Educating Informal Educators on Issues of Race and Inequality: Raising Critical Consciousness, Identifying Challenges, and Implementing Change in a Youth and Community Work Programme. Educ. Sci. 2021, 11, 410. https://doi.org/10.3390 /educsci11080410

Academic Editors: Pam Alldred and Frances Howard

Received: 14 June 2021

Accepted: 22 July 2021

Published: 6 August 2021

Publisher's Note: MDPI stays neutral with regard to jurisdictional claims in published maps and institutional affiliations.

Copyright: (c) 2021 by the authors. Licensee MDPI, Basel, Switzerland. This article is an open access article distributed under the terms and conditions of the Creative Commons Attribution (CC BY) license (https:// creativecommons.org/licenses/by/ $4.0 /)$.

\begin{abstract}
The debate regarding institutional racism and White privilege within higher education (HE) remains prevalent, and higher education institutions (HEIs) are not exempt from the racial equality debate. Youth and Community Work is underpinned by anti-oppressive practice, highlighting a need to educate informal educators on the structural underpinnings of Race and inequlaity, so that they can be challenged in practice to bring about social change. For Youth and Community Workers, this is primarily done through informal education and critical pedagogy. The research aimed to unearth race inequality within the Youth and Community Work programme at Wrexham Glyndŵr University (WGU). Critical reflection methodology was used to deconstruct departmental processes of recruitment, learning and assessment, student voice, and support. Research data was analysed using thematic analysis, determining three themes: critical consciousness, challenge, and change. These are discussed within the framework of Critical Race Theory and critical pedagogy. The research concludes that oppression, and therefore inequality, occurs in the Youth and Community Work programme. Further reading of issues reported in HEIs across the United Kingdom shows that more analysis and deconstruction is needed through CRT. Educating informal educators on issues of race and inequality to raise critical consciousness is one way this can be achieved.
\end{abstract}

Keywords: critical consciousness; critical reflection; inequality; racism; oppression; informal education; Youth and Community Work; social justice; transformative education; higher education; critical pedagogy; Critical Race Theory

\section{Introduction \\ 1.1. Clarifying Concepts: Racism and White Privilege}

When considering the concept of racism, it is useful to explore descriptions of the phenomenon to attempt to understand some of its connotations. There are varying definitions for racism. It encompasses a complex system that affects people in multiple ways. Bhui [1] (p. 130) states that:

"Racism can be understood as an inability to accept and acknowledge differences of race. It might involve the treatment of some people of colour as inferior because they belong to a particular race, and it is usually used to demonstrate disapproval. Where racism is present there is an attempt to control and dominate the object that is felt to be different and separate".

Khan and Shaheen [2] (p. 5) argue that racism is "perpetrated and experienced as a denial of human dignity," and that "for the racist some groups of people simply aren't fully human, and so aren't owed equal moral obligations; nor can they be part of 'our' community" [2]. However, racism not only happens on a personal level but also at a structural level within institutions. Sian [3] discusses definitions of institutional racism, 
arguing that institutional racism is impacted by structural and systemic practices that directly influence the opportunities available to non-White people. Furthermore, it is stated that institutional racism links closely to White privilege as it comprises covert racist values, beliefs, and practices. These impact on, and steer, systemic and institutional standards, behaviours, and expectations, by upholding the status quo from one particular view; the patriarchal hegemonic hierarchy [3]. According to Hesse [4], institutional racism can include, but is not limited to, subtle forms of racism that are "hidden, disguised, unacknowledged [and] denied but which [are] consistent in its impact of strategic effect" [4] (p. 144), therefore influencing institutional and structural environments and expectations in everyday interactions.

White privilege is a structural arrangement that affords undue advantages to "the expressions of Whiteness through the maintenance of power, resources, accolades, and systems of support through formal and informal structures and procedures" [5] (p. 19). For White people this means the colour of their skin will not impact on the trajectory of their life, or be something they are conscious of, and therefore they are not aware of racism experienced by others [6]. Paying attention to White culture and privilege is a missing link in racial equality [7]. Acknowledging White privilege should lead to accountability, as it allows for the recognition of unconscious oppression and discrimination towards non-White people, but also to the challenge of structural oppression that causes racism in the first place [8]. The failure to explore bias and challenge these results in further defensive actions and discrimination [9].

\subsection{Recognising Institutional Racism and White Privilege}

Identifying and challenging the nuances associated with institutional racism and White privilege is difficult, in that they take place in contrast to the "typical" or public understanding of racism [10]. These are hard to identify and so harder to call out, challenge, or dismantle [11]. Such acts of racism may include micro-aggressions; covert acts that can occur as unintentional and/or intentional systems, behaviours, or actions. This can lead non-White people to feel isolated, unsupported, dismissed, and lacking in belief of themselves [12]. The Macpherson Report [13] was seen as a turning point in formally recognising institutional racism, although Sian [3] argues that the definition provided by Macpherson [13] negates that racism is caused by systems or structures of oppression, and is a conflict between individuals of differing ethnic groups [13].

In 2021, the UK Government commissioned a report investigated by the Commission on Race and Ethnic Disparities [14]. The report stated that institutional racism no longer exists within the UK and that family structures and social class had a larger impact than race on how people's lives turned out $[14,15]$. The report was highly criticised by academics, researchers, and race equality charities from across Britain [14,16]. It was argued that more than twenty years on from the MacPherson Report [13], the problem of institutional racism still abounds. This was demonstrated by the resurgence of the Black Lives Matters Movement in 2020 triggered by the murder of George Floyd. The anger and uprising caused by Floyd's death spread across the globe to Britain and prompted the current call for anti-racist movements and the decolonisation of British structures [17].

\subsection{Acknowledging Inequalities within Higher Education Institutes}

It is argued that HEIs are one of the structures that require further scrutiny [18]. Although race inequality seems to be at the forefront of the current agenda, the focus had shifted to other protected characteristics and to social and economic forms of oppression in HE [19]. However, research has shown that racism and racial harassment occur within HEIs, that there is a lack of diverse staff, including senior leadership teams, as well as ethnicity pay gaps and Black, Asian, and Ethnic Minority student awarding gaps [20,21]. Arday \& Mirza [22] (p. V) assert that "there is little recognition of the role played by universities in (re)producing racial injustice," and therefore race needs to be deemed as a legitimate object of scrutiny in both policy and scholarship [22]. To do this, there is a 
need to accept and confront institutional racism and White privilege within universities [5]. Without critical reflection, this could mean that equality of opportunity for Black, Asian, and Ethnic Minority groups may be taken for granted, despite statistics showing that only $26 \%$ of UK students identified as belonging to these groups in 2019/20 [23], with less than $10 \%$ of Black, Asian, and Ethnic Minorities employed as professors within UK HEIs [24].

The Equality and Human Rights Commission [20] report Tackling Racial Harassment: Universities Challenged prompted a response by Universities UK [21] stating that it is crucial for leaders within HEIs to recognise issues pertaining to racial inequalities within their universities. It is argued that institutional racism can be perpetuated within HEIs in the United Kingdom [21]. In a guide entitled Strengthening Race Equality, Cousins et al. [12] argued that racial inequality cannot be tolerated in any form within the HE sector, stating that "ownership, accountability and responsibility" should fall on the institutions and not solely on individuals [12] (p. 3). It should be recognised that the acts of challenging, dismantling, and deconstructing institutional racism should be a collective and deliberate effort; inclusive of student and staff input from all levels of the HEI. Using a whole university approach should enable authentic opportunities for "transformative action" [12]. A number of recommendations have been made at both a school- and HE-level to challenge racism at a structural level. These include increasing the diversity of teaching personnel, increased racial literacy amongst staff, changes to teaching and assessment, and a curriculum that includes the teaching of colonial history [24,25].

\subsection{Informal Education as Transformative Action: Raising Critical Consciousness}

In 2010, Youth and Community Work became a degree entry profession in the UK, and therefore requires completion of an honours degree or postgraduate diploma from an HEI [26]. Foremost, transformative action is a core principle of Youth and Community Work, which is regarded as a countervailing force against the reproduction of social inequalities that formal education magnifies [27]. As a people-centred profession working with young people aged 11-25, Youth and Community Work has a "commitment to diversity, anti-oppressive practice and the provision of relational spaces in which individuals and groups can think critically about their lives and worlds, in order that they might act to shape them differently" [28] (p. xvii). Youth and Community Work is underpinned by the principle of anti-oppressive practice. This involves the recognition that society is fundamentally unjust, that structural and institutionalised oppression creates inequality, and therefore there is a need to work towards the equitable distribution of opportunity, privilege, and wealth across society $[29,30]$. Developing an understanding of the processes by which oppression occurs and maintained is key to anti-oppressive practice, and only by taking a critical stance can these "distortions" be uncovered [31,32].

To bring about transformational action, Youth and Community Work is best described as a process of informal education; valuing the voluntary relationship between Youth and Community Worker and young people, promoting association and experiential learning [33], but also, importantly, raising critical consciousness [34] to empower and promote participation in democratic processes to bring about social change. For Freire [35] (p. 33) this involves developing our own "critical capacity, curiosity and rigour" as well as that of the young people or students involved in the process of education. The work is collective, participatory, and inclusive, and involves people in an active educational process to bring about social justice and critical awareness for transformation and change [33]. This is translated into Youth and Community Work practice as conversation, empowerment, participation, critical thinking, and reflection [36], grounded in experiential learning [37]. As anti-oppressive practitioners, critically reflective practice and reflexivity is essential for self-awareness [29]. The role of the informal education practitioner is "to engage in dialogue with people and community members to enable critical consciousness to challenge oppression" [29] (p. 60). 


\subsection{Critical Pedagogy and Critical Reflection as Tools for Change}

Critical pedagogy is an informal education tool that sets out to facilitate and encourage critical analysis of the world using dialogue [38]. It serves to transform oppressive relations of power, humanising and empowering people through teaching and learning [39]. Fundamental to critical pedagogy are Freire's [34] ideas of conscientisation, raising the critical consciousness of others through questioning their experiences, and praxis, the element of creating change or action. The change in epistemology that results from critical consciousness is a process that creates agency and informs action [40]. The process is inherently political as people connect their experiences with the social and political structures that aid their discrimination to create liberation and social change [41]. Watts et al. [42] argue that there are three key elements to critical consciousness: critical reflection, political efficacy, and critical action. Critical reflection analyses the structural causes of social issues; political efficacy refers to an awareness of the capacity to effect socio-political change; whilst critical action involves actions taken to change society that usually sit outside of mainstream political frameworks [43].

\subsection{Raising Critical Consciousness: A Critical Lens}

Critical pedagogy is underpinned by critical theory [44]. Critical theory assumes that power is transmitted and maintained tacitly by dominant ideologies in society for domination [45] and that any critique of society should lead to action [46]. Foucault's [47] concept of power and Gramsci's [48] theory of hegemony, are tenets of critical theory. For Foucault, power and knowledge are interrelated so that everyone has, and can, execute power [49]. Domination is not a natural way of life but the result of hegemonic processes that need to be explored through critical reflection. By hegemony, Gramsci [48] proposed a process by which a small social class can maintain control over the majority in society, a process that can be overturned by organic and traditional intellectuals establishing a counter-hegemony [50].

Critical Race Theory (CRT) is one such critical theory. Within this research "Race" is acknowledged as a social construct, born in response to the treatment of Black people within the American legal system [51]. It is argued that racial categorisation and factors associated with race are constructed by society [52]. Delgado and Stefancic [51] state that:

“... race and races are products of social thought and relations. Not objective, inherent or fixed, they correspond to no biological or genetic reality: rather, races are categories that society invents, manipulates or retires when convenient ... " (p. 9).

Delgado and Stefancic [51] discuss ways in which racialised minority groups are judged, treated, and discriminated against, based on a notion that has been derived by members who dominate the discourse and benefit from it. It is argued that the impact of racial categorisation directly affects the systems and opportunities available to these groups [53].

"Differential racialisation" highlights the way that the hegemonic [48] or dominant group racialises marginalised people in different ways, and at various times, to suit shifting societal needs [54] (p. 244), suggesting that social constructions of race can be changed over time to uphold the status quo. People have been defined by categorisations based on difference including skin colour. This has resulted in the creation of power, reiterating that the labels provided were created to uphold and maintain power by the "dominant" or "superior" group, thus ascribing privilege to White people over non-White people [55-59].

\subsection{Educating for Change: Youth Workers as Informal Educators in HEI Settings}

As Russo $[60,61]$ argues, to challenge this "... Teachers for social justice need to explicitly acknowledge that injustice exists in society and that, for various reasons, some people are more privileged than others" and so, it is not just Youth and Community Work practitioners, but also Youth and Community Work educators within HEIs that are required to demonstrate the principles of social justice, democracy, and equity through informal education and a commitment to anti-oppressive practices. True transformational 
action can happen when work is completed from the bottom up to challenge top-down approaches [40].

\subsection{Creating Learning Environments: Acknowledgment, Reflection, and Action}

Cousins et al. [12] argue that there is a growing call for HEIs to not only gather and generate data, but also transparently highlight racial inequalities to allow for opportunities to tackle them. It is further stated that HEIs should encourage the development of safe learning environments that challenge working relationships and systems [12]. The purpose of CRT is to critically reflect on the taken-for-granted when analysing race, privilege, and patterns of exclusion [62], and this is required in the context of HEIs, to support them towards becoming more diverse and inclusive [18]. For Zinga and Styres [63], classrooms should be safe spaces to reflect on issues of race, oppression, and positionality, but this requires careful facilitation by educators.

\subsection{Research Aims and Rationale}

To ensure the Youth and Community Work programme at WGU can work to educate informal educators on issues of race and inequality; this research aims to unearth and address oppression in relation to these issues. "To encourage change we need to let go of the belief that we are inhabiting a level playing field" [12] (p. 19), therefore Youth and Community Work educators have a role in this process that begins with becoming critically conscious of structural racism and the impact of White privilege within their own departments, programmes, and educational practice. This will ensure that Youth and Community Work practitioners are aware of racial inequality and discrimination to effectively challenge practice and the structures in which they operate. According to the Welsh Government [64] only 2.2\% of the Wrexham population is recorded as Black, Asian, and Ethnic Minorities, which suggests a greater need, and challenge, for the institution. Figures for WGU show that the proportion of students in these groups rose between 2017 and $2019 / 20$ [23], though the percentage remains low (9\%) in comparison to $23.6 \%$ of students from across UK HEIs who identify as Black, Asian, and Ethnic Minority [65]. In addition, only $8 \%$ of WGU staff sit within this protected group [65], equating to 37 non-White staff compared to 502 White staff employed.

\subsubsection{Demographics of the Researchers}

The staff team on the Youth and Community Work programme has traditionally been comprised of White, privileged academics working in the White patriarchal system of HE. This presented a conundrum, questioning how to create the space for critical pedagogy and raise critical consciousness in academic roles and the wider profession. Improving the programme team's awareness of racism and oppression provides the opportunity to develop confidence and competence around understanding some of the structural issues affecting those who are categorised as Black, Asian, and Ethnic Minority groups [20].

In 2020, the programme team expanded to include a team member whose research is focused on auto-ethnographic and collective narratives of "Mixed-Race" people. The team member's own experiences of racism and oppression provide a unique perspective to discussions around the social constructions of race, offering an opportunity to open dialogical conversation beyond the traditional White middle class and patriarchal perspective $[55,56,66]$. This offered the opportunity for an alternative first-hand perspective of a working-class Black, Asian, and Ethnic Minority experience, in contrast to the White middle class experience the Youth and Community Work programme team had been immersed in. The aim being to make these experiences available to "outsiders" raising critical consciousness and creating social change [67] by unearthing and addressing racial oppression and inequality in the department by developing awareness and understanding [68] so that the programme team may work towards educating informal educators around these issues. 


\subsubsection{Research Objectives}

Based on the discussion above, the research objectives were to:

- Critically reflect on key processes in the Youth and Community Work programme at WGU to identify areas of racial oppression and discrimination

- Critically reflect on the programme team's and students' White privilege and its impact on oppression and discrimination in educational practice and processes

- Identify recommendations to improve the educational practice and processes of the Youth and Community Work programme, and the university, to challenge race based oppression and discrimination.

\section{Methodology and Method}

\subsection{Methodology}

To address the research aim and objectives, critical reflection was adopted as a qualitative explorative tool to understand the research issue [69] and as a research methodology for the investigation [70]. Reflection is widely considered as a pedagogical tool to foster learning, critical thinking, and learning from experience [71]. As such, the process is considered integral to professional practice, particularly for welfare practitioners [29]. As researchers, the participants are also professionally qualified Youth and Community Workers, hence the importance of reflective practice is three-fold in terms of work with young people [72] as informal educators [73] and as adult educators [74,75].

Literature highlights the importance of reflective practice in qualitative research [44], or more specifically, the role of reflexivity in asserting validity and rigour in qualitative research [76]. There is a general acceptance that reflexivity in research accounts for the researcher's self-reflection and analysis of their positionality, how this impacts on the research, and recognising how the research experience might also impact on the researcher $[77,78]$. The research focused on the analysis of interpretations and perceptions of the participants, meaning that the knowledge created could not be objective, "indeed there is no knowledge apart from the researchers' tools, methods, and languages wherewith the research process is accomplished" [44].

Tilsen [79] asserts that the social and relational activity or practice of Youth and Community Work means that it is sympathetic to aspects of constructivism. In terms of questions of ontology, a relativist perspective is taken, and it is understood that there are multiple views of reality that are historically and culturally contingent [79]. These are embedded in either a dominant or marginalized form in linguistic systems. Through dialogue, these dominant or marginalized "versions of reality" may be reinforced or reconstructed [80]. Gormally and Coburn [81] therefore argue that, in Youth and Community Work, knowledge is created through social interaction; people act together to create a social reality; and so, individuals seek to make sense of the world through social interaction. This links Guba \& Lincoln's [82] paradigm of constructivism and to a transactional and subjectivist epistemology that this research embraces [83], challenging positivist ideas of objective knowledge creation [78].

Even though sympathies with constructivism are declared, this research is also informed by Guba \& Lincoln's [82] critical theory paradigm. Whilst critical reflection is founded in critical pedagogy, critical pedagogy is underpinned by critical theory [44]. Critical theory is a tool for exploration and navigation through multifaceted situations when challenging the status quo [84]. Theory and theoretical understanding are always subjective; shaped by our own experiences and the 'lens' through which we see the world [85]. Critical reflection in the critical theory paradigm provides a broader framework for researchers to undertake critical reflection, allowing them to make connections between individual experiences of power and the experiences of others. From a Foucauldian perspective, this is a courageous act as researchers dissect and reject established power structures [49], and simultaneously unearth where they are implicit in these power structures. Brookfield [74] emphasises the importance of critical theory in adult education to create a democratic society and overcome the tacit socio-political assumptions that permeate society. Draw- 
ing on the critical theory paradigm the approach adopted in this research is cognisant of Mertens' [86] assertion that four key characteristics ought to inform research in Youth and Community Work. These are: that research places vital importance on the lives and experiences of marginalized groups, that research analyses how and why inequality exists and is reflected in power relationships, that research examines the results of social enquiry on equality and is linked to social and political action, and lastly, that research uses transformative theories to develop approaches and a theoretical framework [86].

As the epistemology of this research is underpinned by the philosophy that knowledge is socially constructed, it favours the multiple truths, methods, and paradigms of postmodern thinking [87]. Whilst a rejection of any objective truth may be unhelpful [88], the reflexive interrogative nature of the research lends value to this approach as the researchers become more aware of their practices and processes [44]. Although reflexivity has been critiqued by academics as self-indulgent [89,90], or even narcissistic [44], critical reflection within the postmodern paradigm establishes the space to develop new theory and thinking [91] with the view to facilitate social change [90].

\subsection{Method}

The research adopted critical reflection as a qualitative method and methodology to meet the aims and objectives of the investigation. The model of critical reflection adapted for the research is from Fook and Gardner [70] who see the process as:

"the unsettling and examination of fundamental (socially dominant and often hidden) individually held assumptions about the social world in order to enable a reworking of these, and associated actions, for changed professional practice" [70] (p. 21).

The model has mostly been developed as a pedagogical tool (e.g., [92-94]), but it has also been shown to have the capacity to bring about meaningful change $[95,96]$.There are four elements to the model that align with the methodological assumptions underpinning the research, which are: process, theoretical framework, purpose, and setting [92].

In terms of "process" four digital critical reflection sessions of two hours were held to ensure that an equal amount of time and analysis was allocated to each of the four areas of investigation. These were: recruitment and admissions, teaching, learning and assessment, and student support and student voice. The four areas for investigation were chosen because they are processes that influence the structure of the programme from the very start of a student's journey and are directly influenced by the power inherent in the academic roles held by the programme team. The participants in these sessions were the three members of the research team, all of whom identify as women, two of which are White middle-class women. The third woman in the team is Mixed Race and identifies as a Brown person.

Critical reflective tools and dialogue were used to re-count and dissect the current working practices within the Youth and Community Department at WGU. It was assisted by a set of questions adapted from Fook and Gardner [70] (p. 170) (Appendix A). These framed the critical reflection in the philosophical foundations of the research methodology and the "theoretical framework" that influences this model of critical reflection [97], namely reflective practice, reflexivity, post-modernism, and critical theory. The questioning process enabled connections to be made between the researchers and their wider socio-political and cultural contexts to enact social change as the "purpose" of the research, and to develop as anti-oppressive practitioners. These were consequently adapted to meet the demands of the research and "setting," which was a Youth and Community Work programme within a HEI in the United Kingdom.

A qualitative approach was employed to collect data where critical reflections were recorded to allow the team to unpick the rich, verbally generated data. Within the qualitative methodology, thematic analysis $[98,99]$ was chosen for its flexible yet grounded approach. Data was analysed through a thematic analysis [100] of conversations generated through critical reflection methodology [70]. Recordings of the four critical reflection sessions were transcribed, and the data underwent Braun \& Clarke's [100] six phases 
of thematic analysis, which included becoming familiar with the data, generating initial codes, searching for themes, reviewing themes, defining, and naming themes, and then producing them in the section below. This process of data analysis was chosen to enhance the credibility and trustworthiness of the qualitative data generated [99]. It is noted that a hybrid approach to coding and theme development was taken that involved a balance of deductive coding, derived from the experience of the researchers and existing knowledge of the topic, and inductive coding, where themes emerged from the participants' discussions, hence demonstrating further rigour in the research process [101].

\subsection{Delimitations}

Hickson [68] asserts that there are different ways to define critical reflection. These include an interrogation of values and assumptions, an analysis of process and results, and the inclusion of multiple perspectives. Critical reflection relies on multiple perspectives [102,103]. Brookfield [74] stipulates that critical reflection in education should include the four perspectives of the student, the educator, the educator's peers, and a theoretical framework. This research contains a small range of voices; it is limited to the practices and processes of the Youth and Community Work department of the researchers' institution and does not include the voice of students. Furthermore, the "peer lens" [74] is restricted to the full-time teaching team, which could be seen to limit the breadth and depth of analysis. However, the directed, in-depth focused choice of participants creates the space for reflexivity and reaffirms the validity and rigour of the data collection [104].

Fook [105] identifies the critical reflection model used in this research as a two-stage process. The first stage entails analysis and exposure if any hidden socio-political and cultural assumptions are held by the participants. This reflects the four two-hour facilitated critical reflection sessions that the researchers participated in. For Fook [105], the second stage involves dialogue and discussion of the exposed assumptions to direct action. This has partly taken place as the researchers write up the research; however, the time and workload constraints restricted the capacity for further processing, reflection, and discussion.

It is acknowledged that emotional labour may become apparent when reflecting on experiences relating to racism and oppression. Sian [3] argues that, for Black, Asian, and Ethnic Minority staff and students, the psychological strain of being the minority [24] or the "other" $[66,106]$ in HE cannot be underestimated. Where difference is recognised within these groups, Mirza [107] (p. 106) argues that the "emotional and psychological costs to the bearer of that difference" must be acknowledged.

Finally, it is acknowledged that the commitment to praxis as ethical professional informal educators has the potential to conflict with structural practices and processes within the HEI where the researchers are employed. As stated by Jeffs and Smith [33], "informal education and linked methodologies may not engender the smooth operation of bureaucracies and units" (p. 127). This potential for professional dilemmas in unearthing assumptions of power and racism in policies that may implicate the institution could impact on the authenticity of self-reflection and, therefore, the findings of the investigation.

\section{Results}

The research data generated from critical reflection was transcribed and underwent Braun \& Clarke's [99] six phases of thematic analysis, which included becoming familiar with the data, generating initial codes, searching for themes, reviewing themes, defining and naming themes, and then producing them for discussion. The generated themes that came from this process were raising critical consciousness, challenge, and change.

\subsection{Theme 1-Raising Critical Consciousness on Issues of Race and Inequality}

Throughout the research process the team were very aware of the values and principles of Youth and Community Work and their professional identity as practitioners. Discussions focused on how these shaped approaches to recruitment, learning and assessment, support, and student voice specifically in terms of race. One participant stated for example: 
"As Youth and Community Workers our practice, and this programme, should be anti-oppressive due to the principles of empowerment, participation, inclusion and social justice. But I think through our reflections we are going to conclude we could do more in terms of addressing racism and privilege".

The research data highlighted the theme of critical consciousness and awareness in terms of the researchers' perceptions of their own practice and a focus on this for students. Specifically, this increased critical consciousness raised several binaries in terms of professional identity as a Youth and Community Worker versus identity as an academic, education as a process versus education as a product, and social justice versus capitalism.

The process of critical reflection on race, oppression, and White privilege led to an acknowledgement that

"We know we aren't perfect, but we are opening ourselves up to be vulnerable to bring about change".

"Ignorance is bliss, but it's the Youth and Community Work course that brings an awareness about what this all about".

An area of increased critical consciousness was around power and White privilege for the academic staff team. Critical reflection focused on professional identity and conflict between the Youth and Community Worker and the academic. Specifically, as Youth and Community Workers, the focus is on anti-oppressive practice and redressing the balance of power through informal education. However, in formal education, power is afforded to academics, which impacts on decisions to admit students to the programme, the curriculum content, marking assignments, and whether to give voice or not in the class room. Individual critical reflection on power and privilege within the team was therefore essential to ensure that it was not discriminatory towards students, especially those who are Black and from other Ethnic Minority groups. One of the participants said:

"There is power inherent in our roles, we have both the capacity to bring about change, but also, the capacity to reinforce the status quo. At the moment the processes and approaches are not working because whilst our programme is more diverse than others at the university, it is not inclusive for people from Black and Ethnic Minority groups".

However, even within the programme team, an unequal distribution of opportunity and privilege was identified for the Brown participant.

"There is an expectation that universities are places of privilege and are generally not for people like me. This is due to class, but also due to race. I don't feel I fit the stereotype of a White professional or 'academic.' If I feel like that, how do the students feel? How do student's see me?"

Despite the best intentions of the programme team, there was a critical awareness that:

"We are getting unstuck and doing a disservice to Black people. Everyone comes under the one category of widening participation, but different approaches are needed for different groups of people. At the moment there is not equal access".

Therefore, to redress any oppression and discrimination, further discussion was needed to analyse any changes that had and could be made to the programme, and the challenges of upholding a commitment to inclusion and equality.

A further theme brought about from increased critical consciousness was challenges for educational practice at personal, institutional, and structural levels to address issues of oppression, specifically in terms of race. The data revealed an ethical commitment to explore the challenges presented by the increased critical consciousness brought about by the research process:

"Now we are aware there are issues we have a duty to critically reflect on these further. By not identifying what the challenges are, and not actioning them, it's actually worse than being ignorant to them. This is something we also need to consider when we raise the critical consciousness of our students around issues for race, for both the White students but also Black students who are living this on a daily basis".

"We have an ethical duty to act and support, especially now our own critical consciousness has been raised". 


\subsection{Theme 2-Challenges Faced When Deconstructing Institutional Racism}

A number of challenges or barriers were identified for Black, Asian, and Ethnic Minority students in relating to HE processes. Recruitment to the programme was one of the challenges, and whilst the Youth and Community Work programme is more diverse than other programmes at the university, it was acknowledged that there was underrepresentation of Black, Asian, and Ethnic Minority students on the course. The data provided some discussion as to why this was the case, especially in relation to the formal university recruitment process, the UCAS application process, interviews, and the personal statement for application.

"Some Black students may not have had positive experiences of formal education before they get to us. We then expect them to conform to set processes to apply to further formal education. This is going to be a barrier in itself".

The team identified where they had already worked to address this, through more flexibility around entry requirements to the programme, encouraging direct applications, and focusing on informal conversations and workshops as opposed to interviews:

"We take our own initiative and approach to recruitment. We are Youth Workers and so we can be a bit maverick, but whatever changes we make at programme level, we are still constrained by university processes".

"There is an issue here, where we are trying to stick to our Youth Work values and principles, but battling with the view that recruitment processes need to be a certain way in order for the department and the university to be seen as 'professional.'"

It was argued that the lack of diversity on the programme means more responsibility to raise the critical consciousness of White students on their White privilege, as well as supporting students from Black, Asian, and Ethnic Minority groups, which presents a challenge for learning and teaching.

"Due to the demographic of our course we need to flip the script. Our White students need to understand oppression and discrimination, but they also need to acknowledge their White privilege, because they are represented in the majority on this course. They will also be working with young people and communities from diverse backgrounds".

One issue identified was the lack of diversity experienced by White students, battling with colour-blindness or the belief that they do not see race and therefore do not hold racist views. Furthermore, because of personal experiences of oppression from factors such as gender, disability, or class, students cannot recognise their privilege. The challenge is to create learning opportunities in the curriculum to address this, without further alienating Black, Asian, and Ethnic Minority students in the classroom. The data showed critical pedagogy can create space in the classroom for these discussions and for challenging conversations, though this needs to be done carefully and sensitively.

"It's our role to challenge the experiences of privilege and to have those challenging conversations".

"We need to create the opportunities for courageous and challenging discussions with students, using our critical pedagogic approach. This can be about not only creating experiences from which to learn, but also sharing and reflecting on experiences of others. It's our skill as educators to facilitate this".

"This is one of the things that sets us apart from formal education".

Examples were discussed relating to planned group activities, resources, and discussions, however:

"For some of the White students this can make them feel really uncomfortable. If facilitated correctly this can be a good learning opportunity, but for others it is too much. We have had some White students question their values and beliefs and ultimately leave the course".

The research evidenced that learning about race, oppression, and White privilege with colleagues and students has been beneficial for the White participants: 
"I've learnt more about my own White privilege. It's impacted on me personally and my view of the world, but also my pedagogy and ability to challenge. I feel more confident calling out comments, attitudes or behaviour that are essentially racist".

However, this raised issues of authenticity relating to examples and experiences of racism shared in the classroom. For the White participants, this was particularly an issue when discussing racist incidents or experiences of others. For the Mixed-Race participant the issues are around sharing individual experiences and professional boundaries, the emotional labour of reliving these with others, and being challenged about the legitimacy of Critical Race Theory and the concept of White privilege. For the Black students in the class, the team were mindful how learning about race may impact on their relationships with other students, could raise critical awareness about their own lived experiences of racism, and how they should avoid placing any emotional burden on them. Furthermore, when reflecting on covert and overt racist incidents, alongside conducting reading activities to support the group reflections, an awareness was triggered that highlighted incidents in which the Mixed-Race team member recognised that they may have been discriminated against, without realising it at the time.

"It depends how I'm feeling on the day. Sometimes I'm so emotionally exhausted by the challenge, and the relieving of experiences I don't even go there. I know I should because I have the power in the classroom to make it a learning experience. I'm looking round the class for someone else that gets it and I don't want to overly rely on the only other Black or Brown person in the room. It's not their responsibility. It's everyone's responsibility".

A sense of belonging for Black, Asian, and Ethnic Minority staff and students was highlighted as a further issue relating to the lack of diversity on the programme, and the university:

"On paper the values of the organisation mirror my personal values and beliefs in terms of widening participation and inclusion. But the reality is there is no diversity. It is noticeable when I walk through the door I'm not represented here. If I feel like that, how do students feel"?

“There's little representation in the student's union either, or in other university departments. If I need support, where do I go? Where do students go? It's important that those channels are there and to be heard by someone who understands issues of race and racism".

There was also an awareness that any discrimination relating to race was at a structural level, with one participant stating:

"It's bigger than us, and it's really hard to see".

"It goes way beyond the class room. The class room is the safe space to discuss and challenge issues of race, but it needs to go to the structural".

One participant commented that the reflective method of data collection had led to an awareness of her "institutionalisation," more specifically how:

"There's a need to navigate through oppressive systems in the institution. This process of critical reflection has helped me to see this".

Here, the data showed discussion particularly focused on assessment practices, student support, and student voice. Traditional forms of student assessment were seen as oppressive because academic staff have the power to design them, set deadlines, and pass and fail students, all within a system of university processes, regulations, and timetables. The process of requesting extensions was found to be disempowering, because students must explain and evidence their requests. The data showed how this made the participants feel uncomfortable, and further discussion led to the conclusion that, for Black, Asian and, Ethnic Minority students, there was a danger that:

"We think we are empowering people to achieve, but actually are we empowering Black students to feel good about achieving in a colonial system and succeeding in it"? 
At the same time, formal opportunities for hearing the student voice are determined by the university to include scheduled Student Voice Forums and structured module feedback forms at certain points in the year.

"The opportunity for student participation in democratic processes is determined by the organisation. Its encouraged but on their terms, in their format and in their timetable. If students don't fit the structure or don't have experience of formal meetings are they going to want to participate? That may be an issue for some Black students who already have experience of being excluded from participatory and democratic structures, so they don't bother".

\subsection{Theme 3-Change: Informal Education as a Tool for Redressing Inequalities in Higher Education}

The research data evidences a focus on transformation and change and a hope that through Youth and Community Work's distinct approach to education, some of the challenges outlined in the themes above could be redressed.

"It's also not just about how we practice as informal educators, it's about who we are as individuals. It's our belief that education should bring about some form of personal change or transformation. If we can transform someone's belief about race so that it's not oppressive or discriminatory then that has to be a good thing".

"From an informal education perspective, we want to create change, and we believe that we can. It's about working around the barriers to take more holistic and anti-oppressive approach that focuses on social justice and tackles discrimination again Black, Asian, and Ethnic Minority people".

Examples were given of changes that have already been made to challenge oppression and discrimination based on race. These included a redesigned curriculum that ensures a focus on anti-oppressive practice from level 3 to level 7; the addition of an International Youth Work module that focuses on cultural identity and cultural competency; a commitment to decolonising reading lists, the recruitment of a more diverse staff team, and a range of assessment methods to meet the needs and educational experiences of students. These changes could be implemented by other programmes. Additionally, a university-wide project has been developed by the team to engage in conversations to address cultural oppression and encourage discussion about race amongst all departments and levels within the HEI.

"I think we have come a long way in the last five years, but there is more that could be done. It's about acknowledging the achievements made in the department, and embracing the fact that others in the institution may see us as radical, but we see that as a good thing"!

Some areas for future development identified by the data include, firstly, a diverse teaching team of two team members when learning activities and sessions focus on race and privilege, to balance the emotional load and address issues of authenticity. Secondly, consideration of more flexible assignment deadlines determined by students. Thirdly, increased support for Black, Asian and Ethnic Minority students who need to navigate increased critical consciousness about racial oppression and the discrimination they face as result of their learning. Finally, the possibility of an outreach education project in the community with Black, Asian and Ethnic Minority groups. Again, these recommendations are not limited to the Youth and Community Work programme but could be extended across the university.

"If we want to make a real change we need to be out in the communities. We need to be working with diverse groups of people; building relationships, supporting people to feel empowered and ready to participate in education. Often, they need support to overcome the external chaos of their lives and barriers caused by the bigger picture. Until this happens, they are not going to be in a place to come to university and focus on formal education".

"We are good at making those personal connections, this is what we do as Youth Workers, but it's having the time and the space to do this, and I suppose recognition that this our role as academics too. Education isn't about capitalism, it's about social justice". 


\section{Discussion}

By engaging in critical reflection, this research committed to an analysis of the structural causes of racism and a questioning of self through interrogation of ways of doing and thinking [108] in relation to interpretations of White privilege and departmental processes. The critical element of this process and its potential for liberation [75,109] enabled the researchers to adopt "their position as a creature of praxis" [110] to address unintended oppression and dehumanisation [34]. By engaging in authentic dialogue as equals in the learning relationship, and listening to others to make sense of them, the educator needs to let go of their own preconceptions. It is a "humanising speech, one that challenges and resists domination" [111] (p. 131).

\subsection{Theme 1-Raising Critical Consciousness on Issues of Race and Inequality}

The theme of critical consciousness was evident throughout the data, both in raising the researchers' own critical consciousness in terms of race, oppression, discrimination, and White privilege, and that of the students on the programme. The reflexive process enabled critical analysis of positionality in the research, assuring validity and rigour [76] and self-awareness [44]. Grounded in experiential learning theory [37], the reflective process evidenced the first stage of critical consciousness [42] by being critically reflective. This created the space for theory and thinking [94] and praxis in relation to race and privilege so that the need to create change or action became evident [34]. However, this presented conflict between ethical professional practice and structural processes, evidencing the tensions between informal education methodologies and formal institutes [73].

This meant that the research evidences the second stage of critical consciousness, political efficacy [42], or the awareness of the capacity to effect socio-political change [42] in relation to challenging racism within the department, across the university, and in the community. The challenge of enacting structural change was exposed in the findings as paired binaries. These occurred between the seemingly opposite concepts of Youth and Community Worker and academic identities, education as a process or product, and social justice versus capitalism. However, the postmodern thinking underlying critical reflection allows for such conflicts and contradiction, offering a way to deconstruct hegemonic ideas and potentially create new theories for change [105]. In particular, the researchers' roles as professional Youth and Community Workers and academics both hold elements of power. According to Gramsci [48], as academics, researchers can serve as the traditional intellectual, where they are part of the dominant ideology that legitimises knowledge and power to the few that can access university [112].

Conversely, as Youth and Community Workers, the research team are also organic intellectuals [48] committed to the political cause of oppressed groups, and, concurrently, as Youth and Community Work educators in a widening participation university, they are taking part in a counterhegemony, committed to the socio-political cause of the adults they teach [113]. Bell et al. [114] highlight the personal and intellectual challenges facing educators in the classroom when addressing social justice issues. hooks [115] (p. 188) summarises this in asserting that "fear of losing control in the classroom leads educators to fall into conventional teaching patterns where power is used destructively". The distribution of power, however, was not equal for all members of the research team, and consequently, students, but was skewed towards those who identified as White.

\subsection{Theme 2-Challenges Faced When Deconstructing Institutional Racism}

Analysis of the data also raised the theme of challenges, one of which included raising the critical consciousness of students around their White privilege. The researchers asserted that initial conversations with students often led to assertions of "reverse racism" and then to perceived "White victimhood" [6]. This is particularly the case with students who are overwhelmingly from widening participation groups that have faced other forms of oppression due to poverty, disability, sexuality, and gender and do not see themselves as privileged. However, being taught not to see difference results in a failure to explore bias, 
and challenges to this position result in defensive actions [9]. It was therefore identified that the challenge is to create space in the classroom and in the curriculum for conflict and emotion [7] so that personal prejudice and structural racism can be deconstructed by both students and the researchers. The challenge was therefore identified to ensure that the emotional load [12] was not placed on Black students and the only member of the team who is not White.

Johnson [116] argues that a primary obstacle preventing an understanding of racism as a form of systemic oppression is the dominance of the White racial frame [117]. Students' viewpoints, emotions, and ideologies are rooted in this, shaping actions and thinking in everyday situations to rationalise racial hierarchy, yet they are often unaware of this. Bonilla-Silva [118] supports this by stating that students are cautious of discussing race and use colour-blind frames of reference to minimise the salience of racism, and this presents an immediate challenge when teaching about race, especially when there is a lack of diversity in the classroom. Although the Youth and Community Work programmes are more diverse than others at WGU, McIntosh's [8] (p. 11) assertion stands that "many, perhaps most, White students think that racism doesn't affect them because they are not people of colour. They do not see 'Whiteness' as a racial identity". Adopting a critical pedagogy therefore encourages students not only to understand the concept of White privilege but also to acknowledge their own privilege, undoing the formal educational process of teaching people not to see the invisible systems that confer racial dominance [8]. To challenge racism, a pedagogy is required that goes beyond the teaching of concepts to help students develop competing frames of reference, which do more than critique and promote an alternative understanding of reality [116]. Making classrooms a safe space where students and educators can critically reflect on their own positionality is fundamental [63].

The research findings show that the Youth and Community Work programme is in a unique position in which to achieve this safe space. Gulati-Partee \& Potapchuk [7] recommend creating a container with intentional group norms, exploring accumulated advantage and disadvantage, and reflecting on White culture. As Bhopal [5] asserts, there is also a need to move away from a Eurocentric curriculum, which contributes to the normalisation of Whiteness [119]. At times, the Youth and Community Work programme is guilty of relying on content that is stale, male, and pale [120], but any work that makes Whiteness visible must weaken its power [121]. Therefore, through Youth and Community Work education, adopting a critical pedagogical approach in our own classrooms may be one such container with which to challenge.

It was acknowledged in the findings however that one of the challenges was in bringing about change at a structural level, with concerns about institutional processes of recruitment, learning and assessment, support, and student voice. These are not unique to one institution but are reflected across all HEIs [22]. The findings denoted that the research participants have navigated these processes within their programme to bring about greater equality of opportunity, but there was an awareness of the danger of empowering Black, Asian, and Ethnic Minority students and staff "to feel good about achieving in a colonial system and succeeding in it". Critical analysis of what Butters \& Newell [27] (p. 39) term as "cultural adjustment" is needed here to prevent "making people more like us" [8]. This is especially pertinent as Young [36] asserts that the purpose of Youth and Community Work is to support young people's personal and social development, engaging young people during adolescence at a point when identity is formed, helping them to question their identity and role in the world. Supporting young people to explore their racial identity, creating critical consciousness around structural forms of oppression, and empowering young people to challenge this, is crucial to Youth and Community Work and, therefore, the education of Youth and Community Workers.

One tool in which to understand the themes identified in this research, and specifically, a structural understanding of racial oppression and White privilege in HEIs, is Critical Race Theory (CRT) [18]. Specifically, an understanding and application of CRT for staff and students within HEIs can lead to greater awareness of racism in educational settings 
and systematic complexities that further disadvantage Black, Asian, and Ethnic Minority students [18]. Critical race theorists place race and racism at the heart of the analysis of inequality, and so it offers a lens for theorizing the educational inequality discovered in the research to create an educational movement [11]. As anti-oppressive practitioners, the research team can use the assumptions of CRT to understand the White hegemonic oppressions in curriculum, processes and practice presented in the findings [122]. Even though these are unintended, the ideologies and discourses that serve White power become entrenched and unjustified racist policies and practices. The CRT lens assumes it is there and demands action [123]. As with critical theory, Critical Race Theory is critiqued for excessive subjectivity and abstract theorising, and therefore lacking in scientific rigour [122,124]. However, as informal educators and critical pedagogues, through praxis the research team will use the research to inform a critical race pedagogy whilst also taking action to overcome any disclosed inequity in their practice. This will help to embed a commitment to anti-racist policy and practice, moving beyond recommendations to act [125] and work towards the education of informal educators around issues of race and oppression.

\subsection{Theme 3-Change: Informal Education as Tool for Redressing Inequalities in Higher Education}

Analysis of the data identified a third theme of change, which demonstrates the Watts et al. [42] final stage of critical consciousness, critical action. The research was able to identify changes that had already been made to challenge racial oppression and White privilege within the programme and across the university, as well areas for further critical action. These include:

- Ongoing individual and collective critical reflection on power and privilege within the team to navigate binary thinking about professional identity, education, and social justice

- Implementation of changes to the programme to ensure a commitment to inclusion and equality is upheld; these include changes to recruitment, learning and assessment, and student voice and support

- Ongoing individual and collective critical reflection to explore the challenges this presents, and to identify changes to practice in educating informal educators around issues of race and oppression, and specifically around White privilege.

- Some areas for future development identified by the data analysis include:

- A diverse teaching team of two team members when learning activities and sessions focus race and privilege, to balance the emotional load and address issues of authenticity.

- Consideration of more flexible assignment deadlines determined by the students.

- Increased support for Black, Asian, and Ethnic Minority students who need to navigate increased critical consciousness about racial oppression and the discrimination they face as result of their learning.

- The possibility of an outreach education project in the community with Black, Asian and Ethnic Minority groups.

Advance HE [24] explores additional measures that can be taken to overcome structural racism within HEIs. Some of these include visible representation of Black, Asian, and Ethnic Minority staff in all areas; developing robust anti-racist reporting processes for racial harassment and hate crimes; closing the gap on award, retention, and progression of Black, Asian, and Ethnic Minority groups; and making changes to curriculum, research, and reading materials that are representative of contemporary Britain and the diversity of the UK. Arday [126] (p. 3) suggests that:

"Diversity facilitates a collective challenging of stereotyped preconceptions and encourages critical thinking, in addition to facilitating individuals to be able to communicate and engage effectively with people of varied backgrounds". 
By meeting the recommendations for change that arise from this study, it is hoped that the capacity and capability for critical thinking will be enhanced for both staff and students involved in the programme and across the HE sector.

Fedotora \& Nicholaeva [127] discuss the difference between education that can and should be orientated to radical social change, as per the influences of Freire [34] and Giroux [128], and new techniques for teaching and learning that fall outside of the mainstream pedagogies of formal education. To this end, the Youth and Community Work programme adopts a philosophy of education that incorporates both critical pedagogy as a theoretical concept, and as an alternative educational practice, to challenge oppression and encourage and nurture anti-oppressive practice. Smith [38] argues that there is no simple anti-oppression formula that we can follow; we are in a constant state of trial and error and radical experimentation. This is reflective of our position on the Youth and Community Work programmes at WGU as we focus on the education of informal educators around race and inequality. HEIs must allow space to encourage these changes to happen; we "must build communities in order to create a climate of openness and rigor" [67] (p. 40). The research has highlighted that raising the critical consciousness of the team, not only impacts the lives of students but also the structures and systems used within HEIs.

\section{Conclusions}

Through critical reflection on key processes, the research has served to unearth and address hidden inequality in relation to race within the Youth and Community Work programme at Wrexham Glyndŵr University. This includes acknowledgement of the programme team and students' White privilege, its impact on inequality and discrimination in educational practice and processes, and an understanding that this needs further analysis and deconstruction through CRT. The research has led to several recommendations for improving the practice and processes in the Youth and Community Work programme that could be adopted by others. The project could act as a pilot to create a critically reflective tool that can be shared to create action plans for deconstructing racism and oppression across our own institution and beyond. This could, in turn, empower colleagues, institutions, and students to do the same, so that all students, not just informal educators, are educated on these issues.

This research concludes that it is vital to challenge the oppressive structures in HEIs that are facing individuals identifying within Black, Asian and Ethnic Minority groups. It has highlighted that across our own institution and the Youth and Community Work programme, it is the responsibility of White staff and students to work alongside Black, Asian, and Ethnic Minority students to navigate the White-privileged patriarchal hierarchal systems. Despite these conclusions it is important to note that in no way do the researchers claim to be experts with a narrow specialist knowledge of Youth and Community Work. Instead, they are committed to questioning perceived ideas and apparent understandings in the effort to breakdown stereotypes and reductive categories that limit human thought and communication [129]. Their role in acknowledging racial oppression and White privilege within the Youth and Community Work programme is, as Carmichael \& Hamilton [130] (p. 12) state, "to ask the right questions, to encourage a new consciousness and to suggest new forms to express it".

Author Contributions: All authors contributed to all areas of the research and manuscript. All authors have read and agreed to the published version of the manuscript.

Funding: This research received no external funding.

Institutional Review Board Statement: Ethical review and approval were waived for this study because the participants are the authors, in keeping with the methodological framework of critical reflection. There were no additional participants.

Informed Consent Statement: Informed consent was obtained from all subjects involved in the study.

Data Availability Statement: Data is available from request by emailing the authors directly. 
Conflicts of Interest: The authors declare no conflict of interest.

\section{Appendix A}

Critical reflection questions used for the research process and taken from Fook and Gardner [69] (p. 170).

1. What does our account of (insert process) imply about our basic ideals or values, our beliefs about power, our view of ourselves and other people, what we believe about professionalism?

2. Are there any gaps or contradictions between what we say we do and what is implied by what we do?

3. How do I influence the situation through my presence, my actions, my preconceptions or assumptions, other people's perceptions of me, my physical well-being on the day?

4. How have the tools we used to understand the situation affected what we saw?

5. How might I have acted differently if I was from a Black, Asian, or Ethnic Minority group?

6. What does this say about my own biases and preconceptions? How has who I am affected what I noticed or felt was important?

7. What might be the perspective of other players in the situation?

8. Why is mine different?

9. What perspectives are missing from my account?

10. What binaries, or "either-or, forced choice" categories have I constructed?

11. How have I constructed myself, or my professional role, in relation to other people?

12. What do these indicate about the way I am constructing the situation?

13. What assumptions are implicit in my account and where do they come from?

14. How do my personal experience and beliefs from my social context interact in this situation?

15. What functions (particularly powerful functions) do my beliefs hold?

\section{References}

1. Bhui, K. Racism in Mental Health: Prejudice and Suffering; Jessica Kingsley Publishers: London, UK, 2002.

2. Khan, O.; Shaheen, F. Minority Report Race and Class in Post-Brexit Britain. In Runnymede Perspectives; Runnymede Trust: London, UK, 2017.

3. Sian, K. Being Black in a white world: Understanding Racism in British Universities. In Papeles del Centro de Estudios Sobre la Identidad Colectiva; Papeles del CEIC; New York, NY, USA, 2013; Volume 2017/2, pp. 1-26.

4. Hesse, B. Discourse on Institutional Racism: The Genealogy of a concept In Institutional Racism in Higher Education; Law, I., Phillips, D., Turney, L., Eds.; Trentham Books: Staffordshire, UK, 2004; pp. 131-145.

5. Bhopal, K. White Privilege: The Myth of a Post-Racial Society; Policy Press: Bristol, UK, 2018.

6. $\quad$ Eddo-Lodge, R. Why I'm No Longer Talking to White People about Race; Bloomsbury Publishing: London, UK, 2017.

7. Gulati-Partee, G.; Potapchuk, M. Paying Attention to White Culture and Privilege: A Missing Link to Advancing Racial Equity. Found. Rev. 2014, 6, 25-38. [CrossRef]

8. McIntosh, P. White Privilege and Male Privilege: A Personal Account of Coming to See Correspondence through Work in Women's Studies National SEED Project on Inclusive Curriculum; Working Paper 189; Wellesley Centers for Women: Wellesley, MA, USA, 2010.

9. DiAngelo, R. White Fragility. Int. J. Crit. Pedagog. 2011, 3, 54-70.

10. Condit, C.M.; Parrott, R.L.; Harris, T.M.; Lynch, J.; Dubriwny, T. The role of "Genetics" in Popular Understandings of Race in the United States. Public Underst. Sci. 2004, 13, 249-272. [CrossRef] [PubMed]

11. Rollock, N. The Heart of Whiteness: Racial Gesture Politics, Equity in Higher Education. In Dismantling Race in Higher Education: Racism, Whiteness and Decolonising the Academy; Arday, J., Mirza, H., Eds.; Palgrave Macmillan: Cham, Switzerland, 2018; pp. 313-330.

12. Cousins, S. Overcoming Everyday Racism: Building Resilience and Wellbeing in the Face of Discrimination and Microaggressions; Jessica Kingsley Publishers: London, UK, 2018.

13. Macpherson, W. The Stephen Lawrence Inquiry; HMSO: London, UK, 1999.

14. Runnymede. Sewell Reports: Runnymede Responds. 2021. Available online: https://www.runnymedetrust.org/sewell (accessed on 10 June 2021).

15. Mayor, L. Welsh BAME Lives Not Reflected in Racism Report. BBC News. Available online: https://www.bbc.co.uk/news/ukwales-56611091 (accessed on 10 June 2021). 
16. Race Council Cymru. Welsh BAME Lives Not Reflected in Racism Report. Available online: https://racecouncilcymru.org.uk/ welsh-bame-lives-not-reflected-in-racism-report-race-council-cymru (accessed on 10 June 2021).

17. Santiago, A.M.; Ivery, J. Removing the knees from their necks: Mobilizing community practice and social action for racial justice. J. Community Pract. 2020, 28, 195-207. [CrossRef]

18. Hiraldo, P. The Role of Critical Race Theory in Higher Education. Vt. Connect. 2010, 31, 53-59.

19. Pilkington, A. The interacting dynamics of institutional racism in higher education. Race Ethn. Educ. 2013, 16, 225-245. [CrossRef]

20. The Equality and Human Rights Commission. Tackling Racial Harassment: Universities Challenged; The Equality and Human Rights Commission: Manchester, UK, 2019; pp. 6-12. Available online: https://www.equalityhumanrights.com/sites/default/files/ racial-harassment-in-british-universities-qualitative-research-findings.pdf (accessed on 12 June 2021).

21. Universities UK. Universities UK Calls for Urgent Action on Racial Harassment in Higher Education. The Voice of Universities. [blog] The Voice of Universities. 2020. Available online: https://www.universitiesuk.ac.uk/news/Pages/uuk-calls-urgentaction-racial-harassment-higher-education-november-2020.aspx (accessed on 10 June 2021).

22. Arday, J.; Mirza, H.S. (Eds.) Dismantling Race in Higher Education; RacismWhiteness and Decolonising the Academy; Palgrave Macmillan: London, UK, 2018.

23. HESA. Who's Studying in HE? Available online: https://www.hesa.ac.uk/data-and-analysis/students/whos-in-he (accessed on 10 June 2021).

24. Advance, H.E. Equality and Higher Education: Staff Statistical Report 2020. Equality+ Higher Education. Available online: https: / / www.advance-he.ac.uk/media/5941 (accessed on 12 June 2021).

25. Joseph-Salisbury, R. Race and Racism in Secondary Schools. Available online: https://www.runnymedetrust.org/uploads/ publications /pdfs/Runnymede\%20Secondary\%20Schools\%20report\%20FINAL.pdf (accessed on 12 June 2021).

26. Estyn. A Survey of Professional Qualification and Training for Youth Workers; Estyn: Cardiff, UK, 2010.

27. Butters, S.; Newell, S. Realities of Training: A Review of the Training of Adults Who Volunteer to Work with Young People in the Youth and Community Services; National Youth Bureau: Leicester, UK, 1978.

28. Wood, J.; Westwood, S.; Thompson, G. Youth Work Preparation for Practice; Routledge: London, UK, 2015.

29. Chouhan, J. Anti-Oppressive Practice. In Work with Young People; Wood, J., Hine, J., Eds.; SAGE Publications: London, UK, 2009.

30. Thompson, N. Anti-Discriminatory Practice: Equality, Diversity and Social Justice; MacMillan Education: London, UK, 2016.

31. Giddens, A.; Sutton, P. Sociology, 8th ed.; Policy Press: Bristol, UK, 2017.

32. Thompson, N. Promoting Equality: Challenging Discrimination and Oppression, 2nd ed.; Palgrave MacMillan: London, UK, 2003.

33. Jeffs, T.; Smith, M.K. 'What is Informal Education?' The Encyclopedia of Pedagogy and Informal Education. Available online: https: / infed.org/mobi/what-is-informal-education (accessed on 9 June 2021).

34. Freire, P. Pedagogy of the Oppressed; Penguin Education: Harmandsworth, UK, 1972.

35. Freire, P. Pedagogy of Freedom: Ethics, Democracy, and Civic Courage; Rowman \& Littlefield Publishers: Lanham, UK, 1998.

36. Young, K. The Art of Youth Work; Russell House Publishing: Dorset, UK, 1999.

37. Ord, J. John Dewey and Experiential Learning: Developing the theory of youth work. Youth Policy 2012, 108, 55-73.

38. Smith, M.K. Paulo Freire and Informal Education, The Encyclopedia of Pedagogy and Informal Education. 1997, 2002. Available online: https:/ /infed.org/mobi/paulo-freire-dialogue-praxis-and-education/ (accessed on 7 June 2021).

39. Giroux, H.A. Rethinking Education as the Practice of Freedom: Paulo Freire and the Promise of Critical Pedagogy. Policy Futures Educ. 2010, 8, 715-721. [CrossRef]

40. Ledwith, M. Community Development in Action: Putting Freire into Action; Policy Press: Bristol, UK, 2016.

41. Park, P. Knowledge and participatory research. In Handbook of Action Research: Participative Inquiry and Practice; Reason, P., Bradbury, H., Eds.; Sage Publications: London, UK, 2001.

42. Watts, R.; Deimer, M.; Voight, A. Critical Consciousness: Current status and future directions. New Dir. Child Adolesc. Dev. 2011, 134, 43-57. [CrossRef] [PubMed]

43. Hope, E.C.; Bañales, J. Black Early Adolescent Critical Reflection of Inequitable Sociopolitical Conditions: A Qualitative Investigation. J. Adolesc. Res. 2019, 34, 167-200. [CrossRef]

44. Mortari, L. Reflectivity in Research Practice: An Overview of Different Perspectives. Int. J. Qual. Methods 2015, 14, 1609406915618045. [CrossRef]

45. Steinberg, S.; Kincheloe, J.L. Power, Emancipation, and Complexity: Employing Critical Theory. Power Educ. $2010,2,140-151$. [CrossRef]

46. Given, L.M. The SAGE Encyclopedia of Qualitative Research Methods; SAGE Publications: Newbury Park, CA, USA, 2008; Volume 1-0.

47. Foucault, M. The Subject and Power. In Beyond Structuralism and Hermeneutics; Dreyfus, H., Rabinow, P., Eds.; The University of Chicago Press: Chicago, IL, USA, 1983; pp. 208-226.

48. Gramsci, A. Selections from the Prison Notebooks of Antonio Gramsci; International Publishers: New York, NY, USA, 1971.

49. Foucault, M. Discourse and Truth. The Problematization of Parrhesia; Northwestern University Press: Evanstone, IL, USA, 1985.

50. Burke, B. Antonio Gramsci, Schooling and Education. The Encyclopedia of Pedagogy and Informal Education. Available online: http: / / www.infed.org/thinkers / et-gram.htm (accessed on 7 June 2021).

51. Delgado, R.; Stefancic, J. Critical Race Theory: An Introduction, 3rd ed.; Dev Publishers \& Distributors: New Delhi, India, 2017. 
52. Appiah, A.K. The Reith Lectures: Mistaken Identities-Colour. Available online: http://www.bbc.co.uk/programmes/b080t63w (accessed on 20 March 2017).

53. Back, L.; Solomos, J. Theories of Race and Racism. In Routledge Student Readers; Jenks, C., Ed.; Routledge: London, UK, 2001; pp. 1-32.

54. Delgado, R.; Stefancic, J. Critical Race Theory: An Introduction, 2nd ed.; NYU Press: New York, NY, USA, 2001.

55. Caballero, C. From 'Draughtboard Alley' to 'Brown Britain': The ordinariness of racial mixing and mixedness in British society. In International Perspectives on Racial Mixing and Mixedness; Edwards, R., Ali, S., Caballero, C., Song, M., Eds.; Routledge: London, UK, 2012.

56. Aspinall, P. Social representations of 'mixed-race' in early twenty-first-century Britain: Content, limitations, and counter-narratives. Ethn. Racial Stud. 2015, 38, 1067-1083. [CrossRef]

57. Hirsch, A. Brit(ish): On Race, Identity and Belonging; Vintage: London, UK, 2018.

58. Olusoga, D. Black and British: A Forgotten History; Palgrave Macmillan: London, UK, 2018.

59. Akala. Natives: Race and Class in the Ruins of Empire; Two Roads: London, UK, 2019.

60. Russo, A. A Feminist Practice of Antiracism: Strategies to Recognize and Disrupt White Privilege and Power. In Taking Back our Lives: A Call to Action for the Feminist Movement; Routledge: New York, NY, USA, 2001; pp. 207-226.

61. Arshad, R.; Wrigley, T.; Pratt, L. Social Justice Re-Examined: Dilemmas and Solutions for the Classroom Teacher; Institute of Education Press: London, UK, 2012.

62. Parker, L.; Villalpando, O. A race(cialized) perspective on education leadership: Critical race theory in educational administration. Educ. Adm. Q. 2007, 43, 519-524. [CrossRef]

63. Zinga, D.; Styres, S. Decolonizing Curriculum: Student resistances to anti-oppressive pedagogy. Power Educ. 2019, 11, 30-50. [CrossRef]

64. StatsWales.gov.Wales. Available online: https://statswales.gov.wales/Catalogue/Equality-and-Diversity/Ethnicity/ethnicityby-area-ethnicgroup (accessed on 13 June 2021).

65. Wrexham Glyndwr University Equality, Diversity \& INCLUSION Annual Report 2019/2020. Available online: https:/ /www. glyndwr.ac.uk/en/AboutGlyndwrUniversity/EqualityandDiversity/EqualityReports/ (accessed on 10 June 2021).

66. Cabarello, C. Interraciality in Early Twentieth Century Britain: Challenging Traditional Conceptualisations through Accounts of 'Ordinariness. Genealogy 2019, 3, 21.

67. Hooks, B. Teaching to Transgress: Education as the Practice of Freedom; Routledge: New York, NY, USA, 1994.

68. Lapan, S.D.; Riemer, F.J.; Quartaroli, M.T. Qualitative Research an Introduction to Methods and Designs; Jossey-Bass: San Fransico, CA, USA, 2012.

69. Hickson, H. Becoming a critical narrativist: Using critical reflection and narrative inquiry as research methodology. Qual. Soc. Work. 2016, 15, 380-391. [CrossRef]

70. Fook, J.; Gardner, F. Practising Critical Reflection: A Resource Handbook; McGraw-Hill Education: Berkshire, UK, 2007.

71. Coulson, D.; Harvey, M. Scaffolding student reflection for experience-based learning: A framework. Teach. High. Educ. 2013, 18, 401-413. [CrossRef]

72. Thompson, N. Reflective Practice. In Working with Young; Harrison, R., Wise, C., Eds.; Sage: London, UK, 2005.

73. Jeffs, T.; Smith, M. Using informal education in Informal Education. In Using Informal Education; Jeffs, T., Smith, M., Eds.; Open University Press: Buckingham, UK, 1990.

74. Brookfield, S. Becoming a Critically Reflective Teacher; Jossey-Bass: San-Francisco, CA, USA, 1995.

75. Mezirow, J. Fostering Critical Reflection in Adulthood: A Guide to Transformative and Emancipatory Learning; Jossey-Bass: San Francisco, CA, USA, 1990.

76. Dodgson, J.E. Reflexivity in Qualitative Research. J. Hum. Lact. 2019, 35, 220-222. [CrossRef] [PubMed]

77. Gilgun, J.F. Lived experience, reflexivity, and research on perpetrators of interpersonal violence. Qual. Soc. Work 2008, 7, 181-197. [CrossRef]

78. Berger, R. Now I see it, now I don't: Researcher's position and reflexivity in qualitative research. Qual. Res. 2015, 15, 219-234. [CrossRef]

79. Tilsen, J. Narrative Approaches to Youth Work; Conversational Skills for a Professional Practice; Routledge: London, UK, 2018.

80. Wittgenstein, L. Philosophical Investigations, 2nd ed.; Basil Blackwell Ltd.: Oxford, UK, 1958.

81. Gormally, S.; Coburn, A. Finding Nexus; connecting youth work and research practices. Br. Educ. Res. J. 2014, 40, 869-885. [CrossRef]

82. Guba, E.G.; Lincoln, Y.S. Competing Paradigms in Qualitative Research. In Handbook of Qualitative Research; Denzin, N.K., Lincoln, Y.S., Eds.; Sage: London, UK, 1994; pp. 105-117.

83. Probst, B. The Eye Regards Itself: Benefits and Challenges of Reflexivity. Qual. Soc. Work. Res. Soc. Work. Res. 2015, 39, 37-48. [CrossRef]

84. Chiu, L.F. Critical Reflection: More than Nuts and Bolts. Action Res. 2006, 4, 183-203. [CrossRef]

85. Bourdieu, P. Language and Symbolic Power; Polity Press: Cambridge, UK, 1991.

86. Mertens, D.M. Research and Evaluation in Education and Psychology: Integrating Diversity with Quantitative, Qualitative and Mixed Methods; Sage: London, UK, 2005.

87. Denzin, N.K.; Lincoln, Y.S. (Eds.) Handbook of Qualitative Research; Sage: London, UK, 2002. 
88. Thompson, N. Theorizing Practice, 2nd ed.; Palgrave Macmillan: London, UK, 2017.

89. Boud, D.; Walker, D. Promoting reflection in professional courses: The challenge of context. Stud. High. Educ. 1998, 23, 191-206. [CrossRef]

90. Finlay, L. Reflecting on 'Reflective Practice'; Practice-based Professional Learning Paper 52; The Open University: Berkshire, UK, 2008.

91. Morley, C. Using Critical Reflection to Research Possibilities for Change. Br. J. Soc. Work. 2014, 44, 1419-1435. [CrossRef]

92. Fook, J. Beyond Reflective Practice: Reworking the 'critical' in Critical Reflection. In Beyond Reflective Practice: New Approaches to Professional Lifelong Learning; Bradbury, H., Frost, N., Kilminster, S., Zukas, M., Eds.; Routledge: London, UK, 2010 ; pp. 37-51.

93. Morley, C. Critical reflection as an educational process: A practice example. Advances in Social Work and Welfare Education: Special Issue- Critical Reflection. Method Pract. 2011, 13, 7-28.

94. Morley, C. How does critical reflection develop possibilities for emancipatory change? An example from an empirical research project. Br. J. Soc. Work. 2012, 42, 1513-1532. [CrossRef]

95. Morley, C. Developing critical reflection as a research methodology. In Knowing Differently: An Introduction to Experiential and ArtsBased Research Methods; Liamputtong, P., Rumbold, J., Eds.; Nova Science Publishers: New York, NY, USA, 2008 ; pp. $265-280$.

96. Morley, C.; O’Bree, C. Critical Reflection: An Imperative Skill for Social Work Practice in Neoliberal Organisations? Soc. Sci. 2021, 10, 97. [CrossRef]

97. Fook, J. Social Work: A Critical Approach to Practice, 3rd ed.; SAGE: London, UK, 2016.

98. Boyatzis, R.E. Transforming Qualitative Information: Thematic Analysis and Code Development; Sage Publications: London, UK, 1998.

99. Braun, V.; Clarke, V. Using thematic analysis in psychology. Qual. Res. Psychol. 2006, 3, 77-101. [CrossRef]

100. Braun, V.; Clarke, V. Thematic analysis. In APA Handbook of Research Methods in Psychology, Vol. 2: Research Designs: Quantitative, Qualitative, Neuropsychological, and Biological; Cooper, H., Camic, P.M., Long, D.L., Panter, A.T., Rindskopf, D., Sher, K.J., Eds.; American Psychological Association: Washington, DC, USA, 2012; pp. 57-71.

101. Fereday, J.; Muir-Cochrane, E. Demonstrating Rigor Using Thematic Analysis: A Hybrid Approach of Inductive and Deductive Coding and Theme Development. Int. J. Qual. Methods 2006, 5, 80-92. [CrossRef]

102. Moon, J. Reflection in Learning and Professional Development: Theory and Practice; Kogan Page: London, UK, 1999.

103. Hatton, N.; Smith, D. Reflection in teacher education: Towards definition and implementation. Teach. Teach. Educ. 1995, 11, 33-49. [CrossRef]

104. Smith, A. Unsettling the Privilege of Self Reflexivity. In Geographies of Privilege; Winddance, T.F., Gardner, B., Eds.; Routledge: New York, NY, USA, 2013.

105. Fook, J. Reflective Practice and Critical Reflection. In Handbook for Practice Learning in Social Work and Social Care, 2nd ed.; Knowledge and Theory; Lishman, J., Ed.; Jessica Kingsley: London, UK, 2007; pp. 363-375.

106. Alibhai-Brown, Y. Mixed Feelings: The Complex Lives of Mixed-Race Britons; Women's Press: London, UK, 2007.

107. Mirza, H. Racism in Higher Education: What Then, Can Be Done? In Dismantling Race in Higher Education: Racism, Whiteness and Decolonising the Academy; Arday, J., Mirza, H., Eds.; Palgrave Macmillan: Cham, Switzerland, 2018; pp. 3-26.

108. Corlett, J.A. Race, racism, and reparation. J. Soc. Philos. 2005, 36, 568-585. [CrossRef]

109. Carr, W.; Kemmis, S. Becoming Critical: Education, Knowledge and Action Research; Falmer: London, UK, 1986.

110. Andreola, B.A. Action, Knowledge and Reality in the Educational Work of Paulo Freire. Educ. Action Res. 1993, 1, $221-234$. [CrossRef]

111. Hooks, B. Talking Back: Thinking Feminist, Thinking Black; South End Press: Boston, MA, USA, 1989.

112. Heaney, T. Politics of Explanation Ethical Questions in the Production of Knowledge. In Freirean Pedagogy, Praxis, and Possibilities: Projects for the New Millennium; Steiner, S.F., Freire, P., Eds.; Falmer Press: New York, NY, USA, 2000.

113. Mayo, P. Synthesizing Gramsci and Freire: Possibilities for a Theory of Radical Adult Education. In Freirean Pedagogy, Praxis, and Possibilities: Projects for the New Millennium; Steiner, S.F., Freire, P., Eds.; Falmer Press: New York, NY, USA, 2000.

114. Bell, L.A.; Love, B.J.; Washington, S.; Weinstein, G. Knowing ourselves as social justice educators. In Teaching for Diversity and Social Justice; Adams, M., Bell, L.A., Griffin, P., Eds.; Routledge/Taylor \& Francis Group: London, UK, $2007 ;$ pp. 381-393.

115. Hooks, B. Confronting class in the classroom. In The Critical Pedagogy Reader, 2nd ed.; Darder, A., Baltodano, M., Torres, R., Eds.; RoutledgeFalmer: New York, NY, USA, 2009; pp. 135-141.

116. Johnson, A.; Joseph-Salisbury, R. Are you supposed to be in here ... ? In Dismantling Race in Higher Education: Racism, Whiteness and Decolonising the Academy; Arday, J., Mirza, H., Eds.; Palgrave Macmillan: Cham, Switzerland, 2018; pp. 143-160.

117. Feagin, J.R. Racist America: Roots, Current Realities, and Future Reparations, 2nd ed.; Routledge: New York, NY, USA, 2010.

118. Bonilla-Silva, E. Racism without Racists: Color-Blind Racism and the Persistence of Racial Inequality in America, 4th ed.; Rowman \& Littlefield Publishers: Lanham, MD, USA, 2014.

119. Ganley, T. What's all this talk about whiteness? Dialogue 2003, 1, 12-30.

120. National Union of Students. NUS HerStory Month—Where are All the Women? Available online: https://www.nusconnect.org. uk/articles/nus-herstory-month-where-are-all-the-women (accessed on 10 June 2021).

121. Moreton-Robinson, A. Talkin' Up to the White Woman: Indigenous Women and Feminism; University of Queensland Press: St Lucia, Australia, 2000.

122. Hartlep, N.D. Critical Race Theory: An Examination of Its Past, Present, and Future Implications. Available online: https: / / files.eric.ed.gov / fulltext/ED506735.pdf (accessed on 11 June 2021). 
123. Ladson-Billings, G.; William, F.T., IV. Toward a Critical Race Theory of Education. Teach. Coll. Rec. 1995, 97, 47-68.

124. Jackson, B.W., III. Black idenitity development: Influences of culture and social oppression. In New Perspectives in Racial Development: Integrating Emerging Frameworks; Wijeyesinghe, C.L., Jackson, B.W., III, Eds.; NYU Press: New York, NY, USA, 2012.

125. Dixson, A.D.; Rousseau, C.K. They're Trying to Wash Us Away: The Adolescence of Critical Race Theory in Education. In Critical Race Theory in Education; Ladson-Billings, G., Ed.; Routledge: New York, NY, USA, 2006; pp. v-xiii.

126. Arday, J. No One Can See me Cry: Understanding Mental Health Issues for Black and Minority Ethnic Staff in Higher Education. Higher Education. Available online: https://link.springer.com/article/10.1007/s10734-020-00636-w\#citeas (accessed on 12 June 2021).

127. Fedotova, O.; Nikolaeva, E.V. Radical Pedagogy: Theoretical Concept and/or Alternative Practice? Procedia Soc. Behav. Sci. 2015, 186, 785-789. [CrossRef]

128. Harper, V. Neoliberalism, Democracy and the University as a Public Sphere: An Interview with Henry, A. Giroux. Policy Futures Educ. 2014, 12, 1078-1083. [CrossRef]

129. Said, E.W. Representations of the Intellectual: The 1993 Reith Lectures; Pantheon Books: New York, NY, USA, 1994.

130. Carmichael, S.; Hamilton, C.V. Black Power: The Politics of Liberation in America; Vintage Bppks: New York, NY, USA, 1967. 